\title{
RANTAI NILAI INDUSTRI PARIWISATA SUMBA TIMUR DAN SUMBA BARAT DAYA
}

\author{
Hary Jocom ${ }^{1}$, Daniel Daud Kameo ${ }^{2}$, Intiyas Utami ${ }^{3}$, Viktor Bungtilu Laiskodat ${ }^{4}$ \\ Politeknik Bintan Cakrawala ${ }^{1}$ \\ Universitas Kristen Satya Wacana ${ }^{2,3,4}$ \\ haryjocom@gmail.com ${ }^{1}$; ddkameo@yahoo.com ${ }^{2}$; $\underline{\text { intiyas.utami@uksw.edu }}{ }^{3}$
}

Received: January 30, 2021 | Accepted: February 18, 2021 | Published: May 1, 2021

Permalink/DOI: https://doi.org/10.53356/diparojs.v1i2.23

\begin{abstract}
ABSTRAK
Saat ini sektor pariwisata menjadi salah satu prioritas pembangunan di Nusa Tenggara Timur. Terkait dengan hal tersebut maka artikel ini bertujuan untuk membahas dinamika rantai nilai pariwisata di Sumba Timur dan Sumba Barat Daya. Penelitian ini menggunakan metode kualitatif deskriptif menggambarkan dinamika rantai nilai pariwisata di dua kabupaten di pulau Sumba tersebut. Teknik pengumpulan data melalui observasi, transet, dan wawancara mendalam. Hasil dari penelitian ini menunjukkan bahwa Sumba Timur dan Sumba Barat Daya memiliki potensi wisata yang beragam dan kekayaan alam yang belum tereksplorasi semuanya. Potensi dan kekayaan ini memiliki nilai jual yang tinggi jika dikelola secara profesional dan berkelanjutan dengan melibatkan masyarakat lokal. Permasalahan amenitas, akomodasi dan kesadaran wisata masyarakat lokal masih menjadi kendala utama. Namun demikian rantai nilai yang mendukung industri pariwisata telah terbangun walau belum sepenuhnya berfungsi optimal. Dengan maka perlu adanya strategi dan perencanaan pengembangan pariwisata di masa mendatang dengan melibatkan seluruh stakeholders.
\end{abstract}

Kata Kunci: rantai nilai, industri pariwisata, pembangunan, partisipasi

\section{ABSTRACT}

The tourism sector is currently one of the main development priorities of East Nusa Tenggara. As such, the intention of this article is to discuss the dynamics of the tourism value chain in East Sumba and Southwest Sumba. A descriptive qualitative method is used to describe the dynamics of the tourism value chain in these two districts on the island of Sumba. Data was collected through observation and in-depth interviews. The results of this study indicate that East Sumba and Southwest Sumba have diverse tourism potentials and unexplored natural resources. These resources have high economic value if managed professionally and based on sustainable development principles, involving local communities. The main obstacles include 
problems of accommodation, amenities, and tourism awareness by the local community. Nevertheless, the value chain that supports the tourism industry has been established although not yet fully functional. A strategy and plan of action for future tourism development involving all stakeholders is vital.

Key words: value chain, tourism industry, development, participation

\section{PENDAhUluan}

Beragam acara wisata yang ditawarkan telah menarik kunjungan wisata ke Nusa Tenggara Timur. Pada lima tahun terakhir (2014-2018) terjadi kenaikan jumlah wisatawan sebesar 68 persen (BPS NTT, 2019). Kenaikan ini bersamaan dengan adanya program wisata NTT, yaitu "Sail Komodo" serta terbukanya akses pada objek-objek wisata di berbagai wilayah NTT, seperti Pantai Kolbano, taman bawah laut Selat Pantar, Batu Termanu, 17 Pulau Riung, Pantai Nembrala, Air Terjun Oenesu dan Pantai Lasiana. Wisata budaya di NTT juga menjadi daya tarik wisatawan, yaitu kampung megalitikum Bena, upacara Pasola, penangkapan ikan paus secara tradisional di Lamalera, ritual Lowu Podu, upacara adat Reba.

Kekayaan alam dan budaya yang terdapat di NTT merupakan modal dasar dalam pengembangan industri pariwisata dengan berbagai keunikan alam dan beragamnya budaya. Dalam kurun waktu tiga tahun, jumlah kunjungan wisatawan ke NTT menunjukkan tren peningkatan. Tahun 2016, wisatawan yang berkunjung ke NTT sebesar 496.081 orang yang terdiri atas 65.499 wisatawan mancanegara dan 430.582 wisatawan domestik. Jumlah ini mengalami peningkatan dibandingkan tahun 2015 dengan total 441.316 wisatawan. Jumlah kunjungan wisatawan ini semakin bertambah pada tahun-tahun berikutnya, ditunjukkan ada peningkatan wisatawan sebesar 1.192 .442 orang pada tahun 2017 dan pada tahun 2018 bertambah menjadi 1.239.432 orang yang terdiri atas 128.241 wisatawan mancanegara dan 1.111.191 wisatawan domestik (BPS NTT, 2019 diolah). Dari data di atas dapat disimpulkan bahwa pertumbuhan kunjungan wisatawan terjadi juga di Kabupaten Sumba Timur dan Sumba Barat Daya, yang terletak di ujung timur dan barat dari Pulau Sumba. Dinamika industri pariwisata di dua kabupaten tersebut mengalami peningkatan ditandai dengan jumlah kunjungan wisatawan domestik dan mancanegara.

Persiapan dan perbaikan infrastruktur pendukung serta jalur transportasi semakin memudahkan aksesibilitas wisatawan untuk berkunjung. Hal ini didukung kebijakan pemerintah provinsi Nusa Tenggara Timur dengan memprioritaskan pembangunan pariwisata sebagai salah satu program unggulan dalam pengentasan kemiskinan di NTT. Dengan demikian pembangunan pariwisata diharapkan mampu menjadi salah satu kekuatan dan kekayaan yang dimiliki oleh daerah untuk meningkatkan kesejahteraan masyarakat. Selaras dengan kebijakan di tingkat provinsi, pemerintah nasional menetapkan provinsi NTT sebagai salah satu daerah yang pariwisata menjadi prioritas pembangunan nasional. Kebijakan pusat dan daerah ini diharapkan mampu menarik investasi di NTT sehingga dapat menggerakkan roda perekonomian masyarakat.

Sumba Timur memiliki banyak potensi wisata yang dapat dipromosikan dan 
dikembangkan. Berbagai wisata yang ditawarkan meliputi wisata budaya, bahari, dan alam. Wisata budaya dengan menyajikan kekayaan tradisi yang masih dipertahankan turun temurun dalam perbagai acara-acara tertentu yang mengandung filosofi, juga tertuang dalam karya kain tenun masyarakat Sumba. Kesenian lokal yang memiliki daya tarik dan ciri khas. Kekayaan bahari dengan menyajikan keindahan laut, bawah laut, dan ombak. Demikian pula dengan padang savana dilengkapi dengan keanekaragaman flora fauna, serta beberapa kawasan hutan.

Kekayaan wisata yang ditawarkan ini lambat laun mulai dikenal secara luas oleh wisatawan, dibuktikan dengan total jumlah wisatawan mancanegara yang berkunjung ke Sumba Timur selama 5 tahun (20132018) menunjukkan tren peningkatan yaitu sebanyak 14.264 orang di tahun 2013, meningkat signifikan menjadi 26.721 orang pada tahun 2014, terus meningkat menjadi 29.275 orang pada tahun 2015 , di tahun 2016 jumlah wisatawan sebesar 31.618 orang dan 2017 tercatat sebanyak 33.357 orang. Pada tahun 2018 jumlah wisatawan yang berkunjung mengalami peningkatan dibandingkan tahun-tahun sebelumnya, tercatat sebanyak 36.465 orang.

Jumlah terbesar wisatawan didominasi domestik, meski demikian tren kunjungan wisatawan mancanegara semakin naik yang semula hanya 1.764 orang di tahun 2013, menjadi 3.895 pada tahun 2017, namun mengalami penurunan menjadi 1.746 di tahun 2018. Data ini mengindikasikan bahwa pariwisata telah menjadi salah satu industri yang dapat mendorong peningkatan perekonomian daerah melalui peningkatan pendatapan masyarakat.
Sama halnya dengan Kabupaten Sumba Timur, karena masih dalam satu pulau, Kabupaten Sumba Barat Daya memiliki kekayaan wisata yang sama yang dapat ditawarkan pada wisatawan. mengalami peningakatan jumlah wisatawan baik wisatawan domestik maupun mancanegara. Data menunjukkan kunjungan wisatawan sebesar 4.658 pada tahun 2016, meningkat menjadi 5.475 di tahun 2017, dan 8.214 di tahun 2018. Peningkatan jumlah kunjungan wisatawan mancanegara dari 748 orang di tahun 2016, menjadi 1.216 orang pada tahun 2018 . Demikian halnya wisatawan domestik dari 3.910 orang di tahun 2016, menjadi 6.998 orang pada tahun 2018.

Dinamika industri pariwisata di kabupaten Sumba Timur dan Sumba Barat Daya menunjukkan perkembangan yang menjanjikan, berbagai upaya dilakukan oleh pemerintah daerah melakukan promosi untuk meningkatkan jumlah kunjungan wisatawan yang lebih banyak. Sehingga diharapkan dapat berpengaruh pada tingkat pendapatan rumah tangga, pengrajin tenun ikat, dan masyarakat adat lainnya. Sektor ini membuka peluang bagi para pengusaha kecil, menengah, dan besar untuk membangun usaha ekonomi produktif, seperti perhotelan atau penginapan, jasa transportasi, tour guide, rumah makan dan restoran, ticketing tour and travel dan lainlainnya. Dengan terbukanya peluang kerja yang baru, dapat berkontribusi terhadap penurunan angka pengangguran.

Atas dasar tersebut, penelitian ini menemukan keunggulan kompetitif pariwisata di dua kabupaten tersebut melalui analisis dan indentifikasi rantai nilai industri pariwisata yang berada di dua kabupaten tersebut. Di samping itu, mengidentifikasi peluang hambatan yang 
dihadapi dalam pengembangan pariwisata. Penelitian ini diharapkan bermanfaat bagi industri pariwisata Indonesia dan pemerintah daerah sebagai regulator mempunyai gambaran tentang kondisi rantai nilai pariwisata sehingga mampu menetapkan kebijakan yang tepat.

\section{KAJIAN LITERATUR}

\subsection{Analisis Rantai Nilai Pariwisata}

Analisis rantai nilai ini difokuskan pada industri pariwisata sebagai suatu sistem dan mengeksplorasi rantai pasokannya sebagai cara untuk mengidentifikasi peluang bagi masyarakat miskin untuk berpartisipasi dalam berbagai peluang dalam industri pariwisata untuk menyediakan baik itu barang ataupun jasa yang diperlukan, serta lainnya (Sofield \& Lia, 2011). Analisis rantai nilai adalah alat yang memungkinkan untuk melihat lebih dalam aliran ekonomi dan distribusi di dalam sebuah destinasi pariwisata (Giuliani et al., 2005). Melalui pemahaman ini, intervensi dapat direncanakan untuk meningkatkan pengembangan pariwisata melalui kekuatan tata kelola destinasi dan implementasi mekanisme ekonomi (Wood, 2001). Rantai nilai pariwisata melibatkan para pemasok dari sejumlah besar barang dan jasa yang masuk dalam industri pariwisata yang kemudian disajikan kepada wisatawan dalam bentuk produk. Analisis rantai nilai fokus pada sifat hubungan di antara banyak faktor/pemangku kepentingan yang terlibat didalamnya, dan pada dampaknya terhadap pembangunan (Humphrey \& Schmitz, 2002).

Rantai nilai pariwisata berbeda dari rantai nilai manufaktur. Dalam pariwisata, wisatawan adalah pemasar yang mengikuti produk di tempat tujuan (Donovan, 2008). Rantai nilai ini digunakan untuk menganalisis dan sebagai dasar dalam pengembangan destinasi wisata dan menggunakan pariwisata sebagai alat dalam mereduksi kemiskinan (Schoen, 2006). Rantai nilai pariwisata ini dapat dibagi ke dalam berbagai kegiatan, yang saling terkait dan melengkapi satu sama lain untuk memastikan cakupan kompetitif bagi pelaku usaha informal (Vignati \& Laumans, 2009).

Industri pariwisata adalah campuran kegiatan, layanan, dan industri yang memberikan pengalaman perjalanan wisatawan, khususnya perjalanan dan transportasi, akomodasi, tempat makan dan minum, fasilitas pemasaran, hiburan dan aktivitas lainnya, dan layanan perhotelan lainnnya tersedia bagi individu atau kelompok yang akan berpergian atau berwisata (Christopher \& Peck, 2004). Pariwisata adalah seluruh industri perjalanan, hotel, transportasi, belanja dan semua komponen lainnya, termasuk promosi yang melayani kebutuhan dan keinginan wisatawan. Industri pariwisata pada dasarnya adalah industri yang berorientasi pada layanan dan tenaga kerja. Semuanya terdiri dari bisnis milik dari berbagai industri dan sektor lainnya (Kumar Sharma \& Shilpa Jain, 2013). Secara umum, industri pariwisata terdiri dari perhotelan (akomodasi dan dinning), perjalanan (jasa transportasi), dan berbagai bisnis lainnya yang menawarkan layanan dan produk kepada wisatawan. Faktanya, bahwa ini adalah interaksi di antara berbagai bisnis dan organisasi/orang yang menawarkan pengalaman perjalanan yang komprehensif kepada wisatawan.

Seiring dengan pertumbuhan industri pariwisata dan semakin banyak pemangku kepentingan yang terlibat dalam sektor ini, maka pemahaman kolektif yang dibangun adalah bagaimana sektor ini memberikan 
keuntungan secara merata di seluruh sektor yang terlibat.

Upaya ini akan diikuti oleh investasi terhadap infrastruktur pendukung, pembukaan peluang kerja, peluang pendapatan langsung dari wisatawan, dan penciptaan berbagai layanan lain yang mendukung layanan terhadap wisatawan. Dengan berjalannya mekanisme ini maka pemberdayaan masyarakat setempat dapat terwujud. Kondisi ideal yang diharapkan ini tidak semuanya dapat terpenuhi secara proporsional, sebagian besar kasus, manfaat dari industri pariwisata ini tidak terdistribusi secara merata di seluruh rantai yang menimbulkan ekses kesenjangan. Rantai nilai pariwisata ini sebagai sebuah instrumen dalam melakukan analisis tingkat keterlibatan berdasarkan kepentingan dari stakeholders dalam pariwista dan model ekonomi yang berjalan.

Komponen utama dari industri pariwisata secara umum adalah; (1) atraksi wisata/destinasi wisata, (2) akomodasi dan kuliner, (3) transportasi, (4) operator tur, (5) agen perjalanan, dan (6) pusat informasi dan layanan wisata. Tempat wisata atau tujuan wisata dianggap sebagai komponen kunci yang paling penting dari industri pariwisata. Daya tarik menjadi tujuan perjalanan wisatawan untuk mendapatkan hiburan, pemenuhan minat atau pendidikan. Dengan demikian perlu merancang sebuah produk yang dapat memenuhi kebutuhan wisatawan dan penjualan barang-barang bersifat sekunder (Smith, 2015). Atraksi yang disajikan terdiri dari alami dan buatan manusia. Sedangkan daya tari alam meliputi; pemandangan alam, atraksi air, pegunungan, taman nasional, situs sejarah, petualangan di alam, dan lainnya. Atraksi buatan manusia meliputi museum, situs budaya, atraksi kesenian budaya, taman, dan lainnya.

Komponen kedua dari industri pariwisata adalah akomodasi dan makanan, komponen dasar yang diperlukan yang mempengaruhi aliran wisata dan keputusan mereka untuk berkunjung kembali. Akomodasi adalah bagian penting dari infrastruktur pariwisata, pertumbuhan dan pengembangannya. Penyedia akomodasi adalah hotel, motel, wisma, guesthouse, resor, pondokan, dan lain sebagainya. Akomodasi berbeda sesuai dengan jenis tempat wisata. Demikian pula, makanan adalah salah satu faktor utama, untuk bertahan hidup, di mana setiap wisatawan sebagai organisme membutuhkan makanan dan minum.

Komponen kedua dari industri pariwisata adalah akomodasi dan makanan, komponen dasar yang diperlukan yang mempengaruhi aliran wisata dan keputusan mereka untuk berkunjung kembali. Akomodasi adalah bagian penting dari infrastruktur pariwisata, pertumbuhan dan pengembangannya. Penyedia akomodasi adalah hotel, motel, wisma, guesthouse, resor, pondokan, dan lain sebagainya. Akomodasi berbeda sesuai dengan jenis tempat wisata. Demikian pula, makanan adalah salah satu faktor utama, untuk bertahan hidup, di mana setiap wisatawan sebagai organisme membutuhkan makanan dan minum. Salah satu faktor tersembunyi utama yang dipertimbangkan wisatawan dalam memilih tujuan berwisata adalah pertimbangan makanan (Ardabili \& Daryani, 2012). Penelitian tentang kondisi kuliner, makanan, makan \& memasak telah dianggap sebagai bidang studi sosiologi dan antropologi (Beardsworth \& Keil, 1992; Warde \& Martens, 2014). Meski telah diterima bahwa makanan merupakan 
komponen yang sangat diperlukan dalam semua tahap perjalanan wisata, sejumlah kecil penelitian telah dilakukan pada makanan sebagai faktor independen untuk mempengaruhi wisatawan (Hjalager \& Richards, 2002). Dalam sebuah penelitian menyebutkan bahwa makanan telah dianggap sebagai destinasi prospektif sebagai obyek wisata. Makanan laut yang segar di tepi pantai, makanan tradisional, restoran terkenal di hotel mahal, di kapal pesiar atau di pusat komersial utama, semua dibangun untuk tujuan ini. Bahkan, semua negara dan bahkan semua kota memperluas atraksi kuliner mereka yang unik untuk menarik lebih banyak wisatawan. Temuan sebuah penelitian (Enteleca Research and Consultancy Ltd, 2000) menunjukkan bahwa makanan memainkan peran utama dalam membuat setengah dari wisatawan tetap berkunjung dan berbelanja. "Turis makanan" dibandingkan dengan kelompok wisata lainnya, telah menjadi kelompok yang paling setia untuk berkunjung kembali ke destinasi wisata yang ada. Dalam pengambilan keputusan untuk memilih tujuan perjalanan wisata, pertimbangan makanan lokal menjadi penting (McKercher et al., 2008). Bagi Hu dan Ritchie (1993), makanan memegang posisi keempat dalam memandang destinasi wisata sebagai tempat yang menarik. Dalam penelitian serupa, mencari alasan referensi turis untuk berkunjung ke Turki, makanan diidentifikasi sebagai faktor keempat perasaan kepuasan wisatawan dan motif utama mereka (Yüksel \& Yüksel, 2001). Dalam penelitian lain (Enright \& Newton, 2005), makanan telah sebagai daya tarik kedua di Hong Kong, yang keempat di Bangkok dan daya tarik yang kelima di Singapura.
Komponen ketiga dari industri pariwisata adalah transportasi. Transportasi dalam arti sederhana adalah untuk mengangkut penumpang dari satu tempat ke tempat lain. Pada titik itu, transportasi digunakan wisatawan untuk membawa wisatawan dari tempat tinggal ke lokasi wisata (Eden \& Kudrle, 2005). Pengalaman perjalanan dan berwisata para wisatawan dimulai dan diakhiri dengan angkutan. Itulah mengapa sulit untuk mempertimbangkan industri pariwisata tanpa transportasi. Kemajuan transportasi, infrastruktur dan penggunaan teknologi di sektor ini mempercepat peningkatan dan pengembangan sektor pariwisata, dimana mampu membawa wisatawan ke berbagai tujuan di dunia.

Operator tur terdiri dari komponen keempat dari industri pariwisata. Peran utama dari operator tur berbeda dengan agen perjalanan yang menjual/menawarkan liburan dan berbagai produk wisata lainnya, operator tur sebenarnya mengakumulasi komponen dan segmen bagian dari liburan, paket liburan yaitu sarana perjalanan, akomodasi, fasilitas makanan, transfer perjalanan, perjalanan dan layanan lainnya (Edensor, 2001). Operator tur sebagai pedagang besar bisnis perjalanan dan, karena mereka membeli dalam "jumlah besar" pemasok layanan perjalanan, seperti pelaku bisnis perhotelan dan maskapai penerbangan. Mereka akan menawarkan produk lengkap yaitu tur komprehensif untuk dijual ke agen perjalanan atau langsung ke konsumen. Atas dasar fungsi, operator tur dibagi menjadi tiga kelompok; operator transportasi seperti, kapal feri, jalur pelayaran, maskapai penerbangan, transportasi jalan, dan lainnya. Penyedia akomodasi seperti hotel, motel, lokasi perkemahan, apartemen, guesthouse, pusat 
liburan, dan lainnya. Layanan tambahan seperti, agen transfer, operator perjalanan, pemandu wisata, penyewaan mobil, dan asuransi perjalanan. Operator wisata memainkan peran sentral dalam industri pariwisata. Operator tur bertindak sebagai perantara antara wisatawan dan penyedia layanan pariwisata, sehingga mereka dapat memengaruhi pilihan konsumen, melakukan pasokan, dan mengembangkan destinasi. Peran khas ini berarti bahwa operator tur dapat memberikan kontribusi penting untuk mendorong tujuang pengembangan pariwisata berkelanjutan dan melindungi dan memastikan aset lingkungan dan budaya serta sosial yang menjadi tumpuan industri pariwisata untuk keberlangsungan hidup, pertumbuhan dan pengembangannya.

Komponen kelima dari industri pariwisata adalah agen perjalanan, yang dicirikan sebagai perusahaan yang dikuantifikasi untuk mengatur produk dan layanan ritel terkait perjalanan industri pariwisata (Goldblatt, 2002). Peran agen perjalanan dalam bisnis pariwisata dapat di sintesis sebagai; agen perjalanan mempunyai kekuatan untuk mempengaruhi dan mengarahkan permintaan konsumen yang menghubungkan ke indsutri lain; agen perjalanan bukan hanya perantara, mereka bertindak seperti antarmuka di tengah penawaran dan permintaan yang berbeda; agen perjalanan modern memiliki beragam struktur dan koneksi serta hubungan yang sangat kompleks (Paştiu et al., 2015).

Informasi turis dan layanan pemandu merupakan komponen terakhir dari industri pariwisata. Pusat informasi wisatawan (TIC) dapat ditempatkan di titik masuk area (seperti bandara, stasiun kereta api atau stasiun bis) atau titik-titik pusat di kotakota, seringkali dengan rambu-rambu yang mengarahkan pengunjung ke sana. Sebagian besar di dalam TIC terdapat pamflet dan brosur tentang atraksi lokal, peta tujuan lokal untuk membantu pengunjung menemukan temapt-tempat tertentu yang menarik bagi mereka, tempat hiburan dan acara, dan mungkin detail tentang transportasi umum seperti tabel waktu untuk bis dan perjalanan kereta dengan area lokal. Salah satu layanan yang disediakan oleh TIC adalah informasi tentang akomodasi di area tersebut dan banyak yang dapat melakukan pemesanan atas nama hotel dan wisma setempat. Di sisi lain, pemandu wisata atau asisten informasi adalah mereka yang menawarkan secara pribadi saransaran yang lain yang tidak ditemukan dalam buku panduan. Pemandu wisata dapat menemai sekelompok wisatawan di sekitar atraksi atau pada tur tertentu yang disediakan oleh operator tur (paket wisata). Mereka dipilih untuk pekerjaan ini karena keterampilan mereka dan kemampuan mereka untuk mengatur serta mengelola orang, sehingga keterampilan mereka harus mencakup komunikasi dan administrasi. Selain itu, jenis layanan pemandu lainnya termasuk yang secara khusus di obyek wisata, seperti pemandu museum, monumen bersejarah dan lainnya. Mereka biasanya memiliki pengetahuan khusus dan terperinci tentang obyek wisata yang dimaksud dan mungkin dapat melakukan tur dalam bahasa asing tertentu untuk membantu pengunjung dari luar negeri yang tidak berbicara bahasa lokal.

Wisatawan sebagai konsumen akan menerima berbagai layanan sesuai dengan perencanaan dan paket wisata yang mereka pilih. Wisatawan akan melakukan perencanaan awal perjalanan wisatanya ke tempat tertentu, meninggalkan rumahnya, berkeliling di daerah tersebut yang menjadi 
tujuan wisata, dan kembali lagi ke tempat tinggal mereka. Proses ini melibatkan begitu banyak kegiatan dan layanan yang saling terkait yang diminita dan digunakan dari berbagai pemangku kepentingan industri pariwisata. Demikian pula dari sisi pasokan industri pariwisata, masing-masing dan setiap stakeholders menawarkan jasa kepada konsumen (wisatawan) di tingkat yang berbeda. Penyedia pasokan meliputi; operator tur, agen transportasi, penyedia akomodasi dan penyedia makanan.

\section{METODE PENELITIAN}

Penelitian ini dilakukan di Pulau Sumba, tepatnya di Kabupaten Sumba Timur dan Sumba Barat Daya, Provinsi Nusa Tenggara Timur. Jumlah objek wisata yang diteliti 13 lokasi yang tersebar di dua kabupaten (Tabel 1).

Tabel 1. Jumlah Tempat Wisata Lokasi Penelitian di Sumba Timur dan Sumba Barat Daya

\begin{tabular}{|c|c|}
\hline Kabupaten & Objek Wisata \\
\hline \multirow[t]{8}{*}{ Sumba Timur } & Air Terjun Tanggedu \\
\hline & Pantai Walakiri \\
\hline & Kampung Adat Wunga \\
\hline & Pantai Tarimbang \\
\hline & Kampung Raja Lewa \\
\hline & Paku \\
\hline & Kolam Jodoh \\
\hline & Pantai Londa Lima \\
\hline \multirow{7}{*}{$\begin{array}{l}\text { Sumba Barat } \\
\text { Daya }\end{array}$} & Pantai Pero \\
\hline & Pantai Watu Malando \\
\hline & Pantai Kita-Mananga Aba \\
\hline & Laguna Waikuri \\
\hline & Kampung \\
\hline & Ratenggaro \\
\hline & $\begin{array}{l}\text { Kampung Adat Umbu } \\
\text { Koba }\end{array}$ \\
\hline
\end{tabular}

Penelitian ini menggunakan metode kualitatif - deskriptif dengan pertimbangan utama bahwa, diharapkan peneliti dapat menggali lebih dalam makna yang terkandung dibalik fenomena yang ada, dibandingkan hanya sekedar menekankan pengukuran kuantitatif. Kondisi budaya, nilai-nilai, dan keyakinan masyarakat mempengaruhi perilaku mereka, yang kemudian menjadi fenomena yang nampak di permukaan. Lebih dalam lagi, melalui pendekatan kualitatif dapat membantu peneliti melihat gambaran detail dan gambaran besar akar dari fenomena yang muncul ke permukaan saat ini. Melalui metode ini diharapkan dapat memberikan pemahaman dan gambaran utuh.

Variabel yang digunakan untuk mengukur rantai nilai industri pariwisata yaitu, kondisi perjalanan ke obyek wisata, akomodasi yang tersedia, makanan yang disajikan, lokasi belanja cinderamata, kondisi dan ketersediaan transportasi lokal, dan operator tur yang tersedia. Karena pendekatan pulau yaitu Kabupaten Sumba Timur dan Kabupaten Barat Daya, maka analisis melihat secara makro dinamika pariwisata di masing-masing kabupaten yang masih dalam satu pulau yang menjadi lokasi penelitian.

Sumber data sekunder yang digunakan dalam penelitian ini adalah data statistik dari Kantor BPS Provinsi NTT, Kantor BPS Kabupaten Sumba Timur dan Sumba Barat Daya, Provinsi Nusa Tenggara Timur Dalam Angka Tahun 2019 \& 2020, Kabupaten Sumba Timur dan Sumba Barat Daya Dalam Angka 2019 \& 2020, Kantor Bappeda Provinsi NTT, Kantor Bappeda Kabupaten Sumba Timur dan Sumba Barat Daya, Dinas Pariwisata Kabupaten Sumba Timur dan Sumba Barat Daya. Sumber data lainnya didapatkan dari berbagai kajian 
yang telah dilakukan oleh lembaga pendidikan, pemerintah, atau organisasi independen lainnya dengan topik yang relevan dengan pokok utama pembahasan disertasi ini.

Data primer berupa informasi dari para pemangku kepentingan berkaitan dengan pariwisata diperoleh dengan cara observasi, transet ke 13 obyek wisata sebagai lokasi penelitian, diskusi terfokus dan wawancara dengan berbagai pemangku kepentingan dalam sektor pariwisata. Verifikasi data dilakukan dengan metode triangulasi dengan cara cross check antara hasil wawancara, observasi, keterlibatan peneliti dalam observasi (participant observation), dokumen tertulis, arsip dan data tertulis termasuk juga gambar/foto dan audio video.

\section{PEMBAHASAN}

Berikut deskripsi dari rantai nilai pariwisata di Sumba Timur dan Sumba Barat Daya;

1. Perjalanan

Wisatawan yang ingin berkunjung ke Sumba Timur dan Sumba Barat Daya dapat menggunakan dua jenis transportasi, yaitu udara dan laut. Kedua kabupaten tersebut telah memiliki bandar udara yaitu bandar udara Umbu Mehang di Kabupaten Sumba Timur, dan bandar udara Tambolaka di Sumba Barat Daya.

Jika melalui jalur laut, maka wisatawan dapat dapat menggunakan pelabuhan laut Kota Waingapu Sumba Timur dikenal sebagai pelabuhan lama yang merupakan pelabuhan terbesar di Kota Waingapu sebagai tempat bongkar muatnya barang dari Surabaya, hingga kapal penumpang antar pulau. Sedangkan di Kabupaten Sumba Barat Daya memiliki dermaga Pelabuhan Weekeloh. Pelabuhan kapal laut ini menghubungkan dengan Kupang, Bima, dan Surabaya. Tidak hanya membawa logistik barang, namun juga penumpang yang ingin berkunjung ke Pulau Sumba melalui Kabupaten Sumba Barat Daya.

Setelah dari bandar udara atau pelabuhan, maka perjalanan ditempuh melalui darat untuk dapat mencapai obyek wisata dari kedua kabupaten tersebut. Berikut deskripsi perjalanan dari masing-masing destinasi wisata.

Destinasi wisata di Sumba Timur; pertama, Air Terjun Tanggedu merupakan salah satu wisata air terjun yang ada di Kabupaten Sumba Timur. Lokasi objek wisata Air Terjun Tanggedu berada di Kecamatan Kanatang, Desa Mondu, Kampung Tanggedu yang dapat ditempuh 1 jam perjalanan dari pusat kota Waingapu menuju ke arah utara Sumba Timur. Keunikan air terjun ini dibandingkan dengan air terjun lainnya adalah, adanya bebatuan yang unik dan banyak level bebatuan yang memancarkan air. Air terjun yang berasal dari lebih dari dua puluh mata air memberikan air yang jernih dan segar.

Kondisi jalan menuju objek wisata dari Kota Waingapu sudah cukup baik, beraspal hotmix karena merupakan jalan provinsi menuju ke kabupaten lainnya. Pada beberapa lokasi, ditemukan jalan berlubang dan ada jembatan yang putus, sedangkan jalan menuju ke objek wisata dari jalan utama masih dalam pembangunan, sehingga pengunjung melewati jalan lain di sekitar rumah warga. Dari tempat parkir di sekitar 
pemukiman warga menuju Air Terjun Tanggedu pengunjung harus menempuh perjalanan dengan berjalan kaki, menuruni dan menyeberangi sungai. Wisatawan kemudian berjalan di sekitar padang sabana sejauh kurang lebih 2 kilometer, setelah itu menuruni lembah untuk mencapai ke air terjun. Kondisi tangga di titik turunan masih sangat sederhana hanya bebatuan yang dibentuk pijakan, pegangan bambu dan seutas tali tambang untuk pegangan. Terdapat satu jembatan di sekitar daerah Kuta yang menuju ke Tanggedu dan sekitarnya yang putus, sehingga kendaraan dialihkan ke jalan lain yang masih berupa tanah dan jembatan pengganti sementara dari kayu.

Untuk menuju ke objek wisata, penggunaan kendaraan disarankan untuk menggunakan mobil besar (offroad) karena kondisi jalan yang masih belum beraspal dan melewati medan yang berat. Angkutan umum bus dan truk hanya bisa sampai di pinggir jalan besar, sedangkan untuk mencapai objek wisata harus ditempuh dengan kendaraan mobil roda empat kecil. Untuk kendaraan roda dua yang bisa mencapai objek wisata adalah, sepeda motor, motor trail dan sepeda gunung.

Obyek wisata kedua, Pantai Walakiri merupakan salah satu destinasi wisata pantai di Sumba Timur. Lokasi pantai yang kurang lebih $35 \mathrm{~km}$ dari Kota Waingapu bisa ditempuh hanya dalam waktu 20 menit. Pantai ini menjadi salah satu tujuan utama pariwisata untuk wisatawan lokal maupun wisatawan asing. Keunikan dari pantai ini adalah adanya lokasi pohon mangrove, pasir putih yang membentang ke laut ketika air laut surut dan pohon kelapa yang tumbuh miring ke arah pantai. Pantai Walakiri menghadap ke arah timur menjadikan moment sunrise dapat dinikmati dari pantai ini. Belum ada pengembangan di Pantai Walakiri. Pengelolaan masih dikelola oleh masyarakat sekitar.

Kondisi jalan menuju objek wisata sudah beraspal hotmix karena jalan merupakan jalur antarkabupaten (pembangunan jalan untuk persiapan daerah pemekaran Kabupaten Pahungalodo). Jalan menuju ke objek wisata dari jalan besar sedang dalam pembangunan yang nantinya menjadi jalan beraspal. Kondisi jembatan menuju objek wisata dari pusat kota sudah dalam kondisi yang bagus beraspal. Saat ini sedang ada renovasi untuk beberapa deker (jembatan mini/saluran got). Semua kendaraan roda empat dan roda dua bisa digunakan untuk mengakses objek wisata ini.

Ketiga, Kampung adat Wunga terletak di bagian utara Kabupaten Sumba Timur yang berjarak $70 \mathrm{~km}$ dari Kota Waingapu, dengan waktu tempuh dua jam. Kampung Wunga merupakan kampung adat tertua di Pulau Sumba, semua suku dan kampung adat di Pulau Sumba berasal dari kampung ini. Pemuka adat menyampaikan bahwa nenek moyang orang Sumba datang ke Pulau Sumba melewati tujuh lautan, dan delapan pulau melalui Tanjung Sasar, kemudian bermukim di Kampung Wunga ini. Kampung adat ini masih asli dan sudah berumur ratusan tahun terdapat banyak kuburan-kuburan batu dari nenek moyang orang Sumba yang masih ada.

Kondisi jalan menuju ke Kampung Wunga dari Kota Waingapu 
sudah cukup baik, hanya sedikit saja titik jalan yang berlubang. Jalan utama ini merupakan jalan penghubung antara Kabupaten Sumba Timur dan Sumba Tengah. Tangga menuju ke Kampung Wunga sudah dibangun dengan baik. Hanya ada satu jembatan menuju ke lokasi kampung adat di daerah pantai Londa Lima yang terputus, kendaraan pun dialihkan ke jalur tanah dengan memutari pekarangan warga di pinggir pantai.

Kendaraan yang biasa digunakan untuk mengunjungi kampung adat yaitu mobil besar/off road. Jenis kendaraan roda empat lain yang bisa digunakan untuk mengakses lokasi wisata Kampung Wunga adalah pick up, bus kecil dan truk penumpang. Kampung Wunga bisa diakses dengan sepeda motor, motor trail jenis yang lebih baik, dan sepeda gunung.

Obyek wisata keempat, adalah Pantai Tarimbang adalah objek wisata alam yang menawarkan keindahan pemandangan pantai dan ombak surfing. Pantai sepanjang $2 \mathrm{~km}$ ini terletak di antara dua bukit dan memiliki bibir pantai yang lebar. Ketinggian ombak \pm 2-3 meter ini sudah banyak dikenal oleh para peselancar. Pantai Tarimbang sampai saat ini belum dikembangkan secara terkonsep sebagai objek wisata. Namun demikian, destinasi wisata ini sudah banyak dikenal oleh para peselancar dunia.

Pantai Tarimbang berjarak \pm 80 km dari Kota Waingapu. Kondisi jalan dari Waingapu ke Tarimbang dalam kondisi baik, namun setelah melawati pertigaan ke arah Tarimbang kondisi jalan banyak yang rusak dan berlubang. Alat transportasi Pantai Tarimbang hanya ada pilihan mobil rental dan transportasi umum. Jenis mobil Strada atau mobil off road cocok untuk kondisi jalan menuju ke Tarimbang. Transportasi umum menuju Pantai Tarimbang dapat menggunakan truk lokal dengan rute Waingapu-Tarimbang (tarif Rp 25.000,00/orang). Biasanya transportasi umum ini digunakan oleh masyarakat lokal Tarimbang untuk berbelanja berbagai kebutuhan di Waingapu.

Selanjutnya, obyek wisata kelima adalah Rumah Adat Lewa Paku wisata budaya yang menawarkan rumah dan kampung adat yang terletak di atas bukit di Desa Kambupahang Kecamatan Lewa. Rumah Adat ini dibangun oleh marga Matolang berkerjasama dengan 36 kabisu/marga. Nama rumah adat "Uma Manu" yang berarti Rumah Ayam, dimaknai merangkul semua marga Matolang. Ada satu rumah adat yang mendapatkan bantuan renovasi dari Kementerian Pariwisata. Pada umumnya, wisatawan yang berkunjung ke rumah adat adalah wisatawan yang hendak pergi ke Sumba Barat. Di daerah Lewa, selain Rumah Adat Praing Paku Lewa, juga terdapat objek wisata alam Kolam Jodoh, Telaga Cinta, dan kegiatan pengamatan burung endemik.

Kondisi jalan Waingapu - Lewa dalam kondisi yang sangat baik, namun untuk jalan memasuki rumah adat masih dalam keadaan yang kurang baik, masih dalam pengerasan. Untuk menuju ke Kampung Raja Lewa Paku, pengunjung akan melewati kampung penghasil sayur.

Perjalanan ke lokasi wisata dari Waingapu dapat ditempuh dengan menggunakan mobil rental atau 
transportasi umum. Transportasi umum dari Waingapu menuju ke Lewa menggunakan armada bus dengan tarif Rp 25.000,00/orang.

Keenam, obyek wisata Kolam Jodoh adalah kolam yang terletak di Desa Uma Manu, Kecamatan Letis yang berjarak $\pm 50 \mathrm{~km}$ dari Kota Waingapu. Lokasi kolam berada di tengah hutan, sehingga wisatawan harus berjalan melewati areal persawahan warga. Objek wisata ini sudah dibuka sejak tahun 2012, namun baru di tahun 2017 tingkat kunjungan wisatawan semakin banyak.

Kondisi jalan dari Waingapu menuju ke Lewa dalam keadaan yang sangat baik. Namun kondisi jalan dari Lewa menuju ke objek wisata Kolam Jodoh dalam keadaan yang kurang baik. Wisatawan harus melewati jalan perkampungan untuk menuju ke Kolam Jodoh. Selanjutnya untuk masuk ke area Kolam Jodoh, pengunjung harus melewati areal persawahan lalu jalan setapak yang masih apa adanya. Berdasarkan hasil pengamatan, belum ada penataan menuju objek wisata Kolam Jodoh.

Ketujuh, obyek wisata Pantai Londa Lima terletak di Kota Waingapu. Pantai ini cukup ramai dikunjungi oleh pengunjung dari Kota Waingapu dan sekitarnya terutama pada akhir pekan dan hari libur. Obyek wisata ini dikelola oleh Pemerintah Daerah Kabupaten Sumba Timur bekerjasama dengan pihak swasta.

Lokasi Pantai Londa Lima cukup strategis karena dekat dengan pusat Kota Waingapu sehingga mudah dijangkau oleh pengunjung dengan berbagai moda transportasi terutama sepeda motor dan mobil.

Setelah mendapatkan gambaran terkait perjalanan ke tujuh obyek wisata yang telah diidentifikasi, maka selanjutnya bagian ini akan membahas enam obyek wisata yang berada di Sumba Barat Daya. Berikut gambaran detil tentang kondisi perjalanan yang ada;

Pertama, obyek wisata Pantai Pero terletak di Desa Pero Konda, Kecamatan Kodi Kabupaten Sumba Barat Daya. Objek wisata ini berjarak 45 $\mathrm{km}$ dari Kota Tambolaka dengan menyuguhkan pantai dengan pemandangan yang indah terutama ketika sunset. Namun demikian, sebenarnya Pantai Pero mempunyai kombinasi karakter pantai yang beragam. Ada bagian pantai yang berpasir, namun ada juga bagian pantai ini yang merupakan tebing karang. Sehingga, ketika ombak besar menghantam tebing karang maka timbul cipratan air yang cukup besar dan tinggi. Hal tersebut kerap dijadikan latar belakang foto para pengunjung. Selain itu, ombak yang besar di pantai ini seringkali juga dimanfaatkan oleh turis asing untuk berselancar.

Pantai Pero dapat dicapai oleh para pengunjung dari Tambolaka (ibukota kabupaten) dengan cukup mudah. Hal ini karena perjalanan sepanjang 1,5 jam melalui jalan yang telah beraspal. Meski dari pasar Bondo Kodi menunju Pantai Pero merupakan aspal kasar, namun kondisinya masih cukup baik. Selain itu pantai ini juga mudah ditemukan karena sudah ada papan penunjuk arah yang cukup jelas. Ditambah lagi ketika memasuki Desa 
Pero Konda ada gapura nama desa sehingga pengunjung merasa yakin bahwa sudah sampai di tempat yang dituju.

Untuk berkunjung ke Pantai Pero, ada banyak pilihan transportasi yang bisa dipakai oleh pengunjung seperti; (1) pengunjung bisa menggunakan angkutan umum sampai di Pasar Bondo Kodi dan kemudian melanjutkan perjalanan menggunakan ojek sampai di Pantai Pero. Moda transportasi tersebut jarang digunakan oleh wisatawan karena minimnya jumlah angkutan umum dan juga cukup sulit mencari tukang ojek di Pasar Bondo Kodi; (2) memakai jasa ojek dari Tambolaka dengan biaya berdasarkan kesepakatan bersama; dan (3) menyewa mobil dari Tambolaka dengan harga berkisar Rp 750.000,00 Rp 800.000,00 selama sehari penuh. Harga tersebut sudah termasuk jasa sopir dan bahan bakar. Moda trasportasi terakhir tersebut yang paling sering dipakai oleh wisatawan yang berkunjung ke Sumba Barat Daya khususnya ke Pantai Pero. Hal ini karena lebih mudah dan bisa mengunjungi beberapa objek wisata sekaligus.

Kedua, Pantai yang juga muara sungai ini terletak di Desa Panenggo Ede, Kecamatan Kodi Balaghar. Sebagaimana pantai-pantai di pesisir Selatan Pulau Sumba, pantai ini juga mempunyai ombak yang cukup besar. Pengunjung akan disuguhi pemandangan pantai yang masih alami dengan pesona gugusan lima batu karang yang tinggi menjulang. Beberapa karang ini cukup unik di mana bagian bawahnya berongga dan nampak seperti memiliki kaki sebagai akibat proses abrasi terus- menerus selama bertahuntahun.

Pantai ini berjarak $57 \mathrm{~km}$ dari Tambolaka yang merupakan pantai di ujung timur Kabupaten Sumba Barat Daya bagian selatan, karena letaknya yang berdekatan dengan perbatasan Kabupaten Sumba Barat. Jalan sepanjang $57 \mathrm{~km}$ tersebut merupakan kombinasi dari jalan aspal halus sepanjang $42,5 \mathrm{~km}$, jalan pengerasan datar sepanjang $15 \mathrm{~km}$ dan pengerasan bergelombang sepanjang 500 meter.

Pantai Watu Malando sulit dikunjungi jika menggunakan transportasi publik. Karena daerahnya yang terpencil, maka tidak ada angkutan umum yang sampai ke objek wisata tersebut. Sehingga pilihan yang tersedia hanyalah menyewa ojek dari Pasar Bondo Kodi atau dari Tambolaka. Untuk menggunakan jasa ojek, pengunjung perlu memiliki nomor telepon tukang ojek terlebih dahulu, karena di Kabupaten Sumba Barat Daya, kecuali di bandara dan Pasar Radamata, sulit menemukan pangkalan ojek atau tukang ojek yang mangkal. Moda transportasi yang banyak digunakan oleh pengunjung objek wisata ini adalah mobil sewaan yang cukup banyak tersedia di Tambolaka. Beberapa hotel, agen perjalanan maupun perseorangan menyewakan mobil dengan kisaran tarif Rp 750.000,00 - Rp 800.000,00/hari sudah termasuk sopir dan bahan bakar.

Ketiga, Pantai Kita- Mananga Aba terletak di Desa Karuni, Kecamatan Loura. Dari sekian banyak objek wisata pantai dengan pemandangan indah yang dimiliki oleh Kabupaten Sumba Barat Daya, Pantai Kita - Mananga Aba merupakan destinasi wisata pantai yang 
terdekat dengan Kota Tambolaka karena hanya berjarak $13 \mathrm{~km}$. Oleh karena itu Pantai Kita-Mananga Aba sering menjadi tempat rekreasi keluarga saat hari libur. Hamparan pasir putih yang cukup panjang dan juga jernihnya air laut merupakan daya tarik bagi wisatawan asing maupun domestik. Sedangkan ombak yang relatif tenang, menjadikan pantai ini cukup aman bagi pengunjung yang ingin bermain air. Pada awalnya pantai ini bernama Mananga Aba, namun pemilik "Mario Hotel \& Cafe" yang berada di pinggir pantai mengubah namanya dengan pantai "Kita" yang bermakna pantai kita semua. Sehingga pantai ini selalu terbuka untuk umum dan tanpa pagar, meski lahan-lahan di sekitar pantai dimiliki oleh "Mario Hotel \& Cafe."

Dari Tambolaka dibutuhkan waktu 30 menit untuk mencapai objek wisata ini. Jalan menuju Pantai KitaMananga Aba merupakan kombinasi antara jalan aspal hotmix dan aspal kasar yang di beberapa bagian nampak berlubang. Akses jalan sampai di pinggir pantai, ditambah papan penunjuk arah yang banyak terpasang di sepanjang jalan menuju Pantai Kita Mananga Aba, memudahkan wisatawan mencapai lokasi.

Terdapat beberapa alternatif moda transportasi yang dapat dipakai ketika ingin berwisata ke objek wisata ini seperti antara lain menyewa mobil seharga Rp 750.000,00 - Rp $800.000,00 /$ hari sudah termasuk sopir dan bahan bakar, atau menyewa sepeda motor seharga Rp 50.000,00/hari belum termasuk bahan bakar. Wisatawan juga dapat memakai jasa ojek dari Tambolaka, yang harganya berdasarkan kesepakatan antara penumpang dan penyedia jasa ojek. Meski wisatawan juga dapat menggunakan angkutan umum mini bus, namun hal tersebut cukup sulit dilakukan karena angkutan umum tidak sampai ke objek wisata (harus dilanjutkan dengan ojek) dan jumlah angkutan umum yang terbatas.

Obyek wisata keempat, Laguna Waikuri merupakan sebuah danau air asin yang berada di Desa KelenaRonggo, Kecamatan Kodi Utara (42 km dari Kota Tambolaka). Tebing karang tinggi memisahkan laut dengan laguna ini. Air laut masuk melalui sela-sela batu karang. Kedalaman air di Laguna ini tergantung pada pasang surut air laut yang ada di balik tebing karang. Pengunjung dapat menikmati pemandangan indah laguna dengan air yang jernih. Dari atas tebing karang, pengunjung dapat melihat dasar danau. Selain itu para pengunjung juga dapat merasakan air Laguna Waikuri dengan masuk langsung ke laguna untuk sekedar bermain air, berenang, atau pun lompat dari menara yang sudah dibangun oleh pihak pemerintah daerah. Semakin lama, objek wisata ini semakin ramai dikunjungi, terlebih ketika hotel atau pun travel agent memasukkan objek wisata ini sebagai salah satu paket andalan. Waktu-waktu sepi pengunjung terjadi pada musim penghujan yaitu bulan Januari - Maret.

Kondisi jalan menuju objek wisata Laguna Waikuri merupakan kombinasi antara jalan aspal hotmix, jalan aspal berlubang dan jalan pengerasan sepanjang $10 \mathrm{~km}$ yang berupa tanah berkerikil. Untuk sampai ke Laguna Waikuri, perjalanan harus melalui jalanjalan perkampungan penduduk yang 
jarak antarrumah saling berjauhan, dan lahan tidur yang nampak tidak terurus mengakibatkan semak belukar menutupi jalan. Bagi pengunjung yang baru pertama kali ke Laguna Waikuri seringkali mengalami kesulitan untuk mencapai objek wisata ini, karena minimnya papan penunjuk arah. Sedangkan ada cukup banyak persimpangan ketika mulai masuk dari jalan kabupaten. Upaya untuk mendapatkan bantuan dari aplikasi Google Maps juga sia-sia karena sinyal telepon/internet lemah dan seringkali hilang. Sedangkan untuk bertanya kepada warga sekitar, kadang tidak mudah karena di persimpangan jalan tidak ada rumah penduduk. Oleh karena itu, bagi wisatawan yang belum pernah ke Laguna Waikuri, disarankan untuk menyewa mobil dari Tambolaka dengan pengemudi yang sudah mengerti jalan ke Laguna Waikuri. Harga sewa mobil di Tambolaka berkisar antara Rp 750.000,00 - Rp 800.000,00/hari sudah termasuk biaya sopir dan bahan bakar. Wisatawan juga dapat menyewa ojek dengan harga sesuai kesepakatan bersama. Jumlah ojek motor terbatas sehingga tidak mudah ditemukan oleh wisatawan. Transportasi publik tidak memungkinkan karena tidak ada angkutan umum yang sampai di Laguna Waikuri.

Selanjutnya obyek wisata yang kelima, Kampung Adat Ratenggaro, berada di Desa Maliti Bondo Ate, Kecamatan Kodi Bangedo yang berjarak 56 km dari Kota Tambolaka. Kampung adat ini awalnya berdiri di tepi Pantai Ratenggaro yang menghadap ke Samudera Hindia, akan tetapi abrasi memaksa penduduk memindahkan kampung adat ini ke tempat yang lebih tinggi. Di pinggir pantai, masih ditemukan jejak kampung adat ini yang berupa kubur batu kuno berukuran besar (dua kali tinggi orang dewasa) dan terbuat dari batu alam. Diceritakan bahwa batu kubur tersebut berasal dari zaman megalitikum (4.500 tahun yang lalu). Di kawasan kampung adat ini terdapat delapan rumah adat tradisional yang terbuat dari bahan lokal dan berasal dari alam (bambu, alang-alang, tali rotan, dan kayu) dengan atap yang menjulang hingga 20 meter. Di tengahtengah kampung adat berdiri rumah adat utama di mana Rato (Raja) tinggal.

Kondisi jalan menuju Kampung Adat Ratenggaro dari Tambolaka beraspal halus tanpa ada kerusakan yang besar. Jalan pengerasan hanya sebagian kecil saja yaitu ketika mendekati Kampung Adat Ratenggaro. Ada beberapa alternatif yang bisa dipakai oleh pengunjung untuk mencapai Kampung Adat Ratenggaro misalnya; (1) pengunjung bisa menggunakan angkutan umum sampai di Pasar Bondo Kodi, kemudian dilanjutkan menggunakan ojek sampai di Kampung Adat Ratenggaro. Namun moda transpotasi tersebut jarang digunakan oleh wisatawan karena minimnya jumlah angkutan umum, dan cukup sulit mencari tukang ojek di Pasar Bondo Kodi; (2) memakai jasa ojek dari Tambolaka dengan biaya berdasarkan kesepakatan bersama; dan (3) menyewa mobil dari Tambolaka dengan harga sekitar Rp 750.000,00 - Rp 800.000,00 untuk berkeliling seharian. Harga tersebut sudah termasuk jasa sopir dan bahan bakar. 
Obyek wisata keenam, adalah Kampung Adat Umbu Koba terletak di Desa Delo, Kecamatan Wewewa Selatan yang berjarak $40 \mathrm{~km}$ dari Tambolaka. Kampung adat ini berada di puncak bukit dengan jalan yang menanjak dan berkelok. Selain menikmati rumah-rumah adat yang berjumlah 40 unit dan masih terjaga keasliannya, pengunjung juga dapat menikmati pemandangan alam dari atas bukit. Kampung adat ini masih memegang kepercayaan Merapu secara kuat yang mana setiap bulan November selama satu bulan diadakan ritual adat Wulla Poddu yang berarti penyucian diri. Ritual ini juga merupakan penanda masa tanam padi atau pun jagung.

Untuk mencapai Kampung Adat Umbu Koba, wisatawan harus menempuh perjalanan sejauh $40 \mathrm{~km}$ yang dapat ditempuh dalam waktu satu jam dari Tambolaka. Kombinasi jalan hotmix dan jalan aspal kasar menanjak serta berkelok-kelok di mana banyak bagian yang sudah rusak (kerikil terlepas), sehingga cukup membahayakan pengunjung yang menggunakan mobil atau sepeda motor. Kelemahan yang ditemukan dalam aksesibilitas adalah tidak tersedianya penunjuk arah menuju objek wisata pada beberapa persimpangan jalan sehingga cukup menyulitkan pengunjung. Transportasi yang memudahkan untuk berkunjung ke obyek wisata ini dengan menggunakan mobil sewaan dari Tambolaka. Kondisi jalan yang terjal dan berkerikil akan menyulitkan pengemudi untuk mencapai lokasi wisata ini.

2. Akomodasi
Penyediaan fasilitas penginapan di ketujuh lokasi wisata Sumba Timur di atas belum tersedia. Ada delapan hotel nonbintang yang bisa dijadikan rujukan tempat menginap di Kota Waingapu. Pola wisatawan dari luar yang berkunjung ke Sumba Timur biasanya setelah mereka dari lokasi wisata tertentu, makan akan kembali ke Kota Waingapu untuk beristirahat.

Berbeda dengan Sumba Timur, dari enam destinasi wisata Sumba Barat Daya di atas, ada tiga lokasi wisata yang memiliki penginapan, berikut deskripsi akomodasi dari tiga destinasi wisata tersebut; pertama, Pantai Pero, baru tersedia satu penginapan yaitu homestay Mercy. Homestay ini dimiliki oleh Kepala Desa Pero Konda dan dikelola oleh adiknya. Homestay tersebut menyediakan delapan kamar standar dengan biaya $\mathrm{Rp}$ 250.000,00/malam dengan fasilitas kamar mandi dalam dan makan tiga kali sehari, tetapi tidak ada pendingin udara dan televisi. Kondisi homestay cukup sederhana dan bersih. Peminat homestay ini adalah wisatawan asing yang ingin berselancar di Pantai Pero.

Kedua, obyek wisata Pantai KitaMananga Aba memiliki homestay yang bernama Mario Hotel yang baik dan berlokasi di pinggir pantai. Tamu hotel menikmati pemandangan pantai pasir putih dengan air biru jernih yang sangat indah. Meskipun Mario Hotel" memiliki nama hotel namun masih masuk kategori homestay, dengan fasilitas yang baik. Tidak jauh dari Mario Hotel \& Cafe, terdapat juga penginapan Oro Beach Bungalow di Pantai Oro dan Sumba Hotel School. Mario Hotel \& Cafe dan juga Oro Beach Bungalow 
keduanya dimiliki oleh Warga Negara Indonesia (WNI) yang berasal dari Bali dan Flores. Sedangkan penginapan Sumba Hotel School yang juga merupakan sekolah pariwisata didirikan oleh seorang berkewarganegaraan Jerman. Mario Hotel \& Cafe juga menyediakan restoran dengan berbagai menu masakan dan minuman. Selain menyediakan menu masakan yang biasa seperti nasi goreng, mie goreng, dll, restoran ini juga menyediakan aneka masakan dari ikan laut.

Ketiga, di Kampung Adat Ratenggaro, pengunjung dapat menginap di rumah-rumah adat yang berjumlah delapan unit. Meski kondisinya sederhana, namun banyak turis (terutama turis asing) lebih memilih menginap di rumah-rumah adat tersebut, karena bagi mereka sebuah petualangan dan pengalaman baru bisa berinteraksi di wilayah pedalaman, dengan masyarakat yang masih melestarikan peninggalan budaya dan adat. Awalnya untuk menginap di homestay kampung adat tidak ada tarif yang ditentukan karena ditakutkan akan menjadi komersil. Tetapi seiring perkembangan pariwisata, banyak agen perjalanan yang menawarkan kampung adat ini sebagai salah satu destinasi dalam paket wisata. Selanjutnya dikenakan biaya untuk menginap sebesar Rp 200.000,00. Untuk kerja sama dengan agen perjalanan, kampung adat tidak ingin menjadikan hal tersebut hubungan bisnis sehingga tidak ada fee untuk agen perjalanan.

Selain akomodasi yang disediakan di tiga lokasi wisata tersebut, bagi wisatawan lain yang berkunjung ke Sumba Barat Daya dapat menginap di
Tambolaka. Ada 12 hotel nonbintang yang tersebar di Tambolaka.

3. Makanan

Penyediaan layananan makanan disetiap tujuan wisata belum dilengkapi dengan fasilitas restauran atau rumah makan. Hanya Pantai Kita-Mananga Aba menfasilitasi dengan rumah makan bagi pengunjung lokasi wisata. Selebihnya untuk makanan wisatawan harus kembali ke kota terdekat baik itu di Tambolaka atau di Waingapu. Jadi wisatawan akan membawa perbekalan sendiri selama berwisata di obyek tersebut di atas.

Fasilitas rumah makan di Kota Tambolaka terdapat 22 rumah makan, sedangkan di Kota Waingapu lebih banyak dengan jumlah 64 rumah makan. Makanan yang disajikan berupa makanan nasional dan seafood yang sedikit membedakan.

4. Belanja

Kerajinan tangan yang paling banyak ditemui dan menjadi icon wilayah Sumba adalah kain tenun Sumba yang terkenal bagus dan berkualitas baik. Kain ini banyak dijual di toko cinderamata di Kota Tambolaka atau Waingapu, selain pernak-pernik yang lain sebagai icon budaya Sumba.

5. Perjalanan Lokal

Infrastruktur jalan yang baik, menjangkau seluruh lokasi wisata di Sumba Barat Daya maupun Sumba Timur, mempermudah sarana transportasi baik itu kendaraan mobil atau motor menuju ke lokasi wisata. Ketersediaan rental kendaraanpun dapat ditemui dengan mudah, bahkan mereka telah bekerjasama dengan agen 
perjalanan wisata atau ada beberapa kendaraan milik perorangan yang bekerjasama dengan pihak penginapan. Pemilik rental ini ada secara perorangan atau yang dalam bentuk unit bisnis/agen rental yang dimiliki oleh masyarakat Sumba. Ketergantungan terhadap penggunaan transportasi umum untuk menuju lokasi wisata yang masih menjadi kendala karena keterbatasan armada/unit, sehingga tidak dapat menjangkau seluruh tempat.

\section{Operator Tur}

Objek wisata di Sumba telah menjadi salah satu destinasi popular baik wisata alam dengan pantai dan alam yang indah, dan wisata budaya dengan peninggalan kampung adat, makam raja-raja, dan desa tenun. Daya tarik yang ditawarkan cukup eksotik mendorong wisatawan domestik dan mancanegara untuk berdatangan ke Sumba menikmati alam, mempelajari budaya sekaligus berpetualang.

Hampir semua agen perjalanan wisata yang telah terkoneksi secara daring (jaringan website internet) ikut menawarkan paket wisata ke Pulau Sumba. Namun belum semua obyek wisata yang ada di Sumba ditawarkan oleh agen tour tersebut. Hanya destinasi popular saja yang ditawarkan oleh mereka, semisal Pantai Walakiri, Air Terjun Tanggedu, Kampung Adat Ratenggaro, dan lainnya. Dari tiga belas obyek wisata yang diidentifikasi dalam penelitian ini, hanya lima destinasi wisata yang ditawarkan oleh agen perjalanan wisata, untuk Sumba Timur adalah Taman Wisata Londa Lima, Air Terjun Tanggedu, Pantai Walakiri, dan Sumba Barat Daya adalah Laguna Waikuri dan Kampung Adat Ratenggo.
Destinasi wisata selebihnya tidak ditawarkan dalam promosi mereka. Tidak hanya paket perjalanan wisata, perusahaan yang menyediakan layanan pemesanan tiket pesawat dan hotel secara daring daring dengan fokus perjalanan domestik di Indonesia turut menfasilitasi penginapan di Pulau Sumba.

Beberapa situs yang menawarkan tidak hanya pemesanan hotel dan tiket secara daring, tapi juga menawarkan paket perjalanan wisata ke Pulau Sumba yaitu; https://indonesia.tripcanvas.co/id/, https://www.airbnb.com/, dan https://www.tripadvisor.co.id/. Tidak hanya agen perjalanan daring saja, banyak agen tour lokal yang menawarkan perjalanan wisata ke beberapa lokasi wisata yang menarik.

\section{PENUTUP}

Dari pembahasan di atas maka dapat disimpulkan bahwa rantai nilai pariwisata di Sumba Timur dan Sumba Barat Daya belum terkoneksi dan mendukung antarkomponen. Hal ini disebabkan oleh belum adanya perencanaan dan pengembangan produk pariwisata atau aspek penawaran yang belum dipersiapkan dengan baik. Sehingga tidak mampu mendukung berbagai atraksi menarik yang ditawarkan. Berikut penjelasan dari masing-masing komponen;

Komponen perjalanan secara umum lokasi objek wisata sudah dapat dijangkau dengan menggunakan transportasi darat, demikian pula dengan prasarana jalan yang tersedia dengan kondisi baik. Persoalan hanya pada amenitas yang masih terbatas semisal papan informasi penunjuk arah menuju lokasi wisata, ataupun fasilitas 
pendukung lainnya di lokasi wisata, baik itu toilet umum, fasilitas pembuangan sampah, layanan kesehatan, dan lainnya.

Pada komponen akomodasi nampak jelas bahwa tidak semua di sekitar objek wisata menyediakan fasilitas penginapan. Keadaan ini menjadikan pola perjalanan wisatawan single point, dan masyarakat tidak menerima keuntungan dari industri pariwisata di wilayah mereka dengan membangun homestay. Berbeda jika dalam sebuah kawasan terdapat beberapa objek wisata, perencanaan pembangunan dan pola perjalanan wisatawan dapat diarahkan menggunakan pola perjalanan destination region loop atau stop over, sehingga dapat disediakan akomodasi bagi wisatawan yang ingin menghabiskan waktu berwisatanya lebih lama lagi.

Makanan dalam industri pariwisata telah menjadi salah satu komponen penting bahkan menjadi daya tarik tersendiri (Sormaz et al., 2016). Tidak adanya makanan khas yang disajikan bagi wisatawan yang berkunjung sedikit mengungangi identitas dan daya tarik kekhasan kuliner lokal (Sormaz et al., 2016).

Komponen belanja telah mampu menampilkan identitasnya melalui penjualan kain tenun walau masih terbatas di kota Tambolaka dan Waingapu. Selain sebagai sebuah identitas budaya masyarakat lokal, kerajinan tenun ini mampu menggerakkan perekonomian masyarakat pengrajin.

Kemudahan mendapatkan berbagai moda transportasi bagi wisatawan yang ingin berkunjung ke objek wisata mempermudah perjalanan wisata. Moda yang disediakan oleh masyarakat baik secara perorangan maupun telah bekerjasama dengan berbagai penginapan mengindikasikan telah terbangunnya rantai nilai antarkomponen unsur kegiatan perjalanan pariwisata.

Komponen yang terakhir yaitu operator tur menjadi komponen penting dalam industri pariwisata atau perjalanan wisata. Karena operator tur yang mengatur seluruh rangkaian perjalanan wisatawan dan sejak wisatawan tersebut berangkat dari rumah hingga kembali lagi ke rumah mereka. Operator tur mengkoordinasikan seluruh unsur kegiatan yang ada dalam kegiatan perjalanan wisatawan tersebut. Dalam konteks penawaran untuk berwisata di Sumba Timur dan Sumba Barat Daya telah berjalan baik melalui media daring maupung lokal.

Secara terperinci telah dideskripsikan seluruh rangkaian rantai nilai industri pariwisata di Sumba Timur dan Sumba Barat Daya, bahwa komponen akomodasi dan makanan yang belum terkoneksi. Karena belum adanya perencanaan dan pengembangan kawasan objek wisata yang ada secara menyeluruh, yang memungkinkan bagi seluruh komponen atau elemen dalam industri pariwisata tersebut dapat terhubung dan mendukung.

Satu hal yang penting dalam membangun industri pariwisata di Sumba Timur dan Sumba Barat Daya adalah mendorong partisipasi masyarakat sekitar sebagai stakeholders inti, dapat menstimulasi kesadaran kritis mereka untuk menjaga serta menjadi salah satu pelaku bisnis dalam rantai pariwisata tersebut. Di masa mendatang, pembangunan pariwisata di Sumba Timur dan Barat Daya dapat diarahkan pada pariwisata berbasis masyarakat, di mana masyarakat adat terlibat dalam pengembangan dan optimalisasi kekayaan budaya dan alam 
yang dikemas dan dikelola bersama antara masyarakat dan private sektor.

\section{DAFTAR PUSTAKA}

Ardabili, F. S. and Daryani, S. M. (2012) 'Customer satisfaction based on the missing aspects: Instinct factors and emotion', Australian Journal of Basic and Applied Sciences, 6(12), pp. 86-90.

Australia, T. W. (2010) Annual Report 2009, Annual Report 2009. doi: 10.2499/9780896297852.

Beardsworth, A. and Keil, T. (1992) 'The vegetarian option: varieties, conversions, motives and careers', The Sociological Review, 40(2), pp. 253-293. doi: 10.1111/j.1467-954X.1992.tb00889.x.

Chahal, H. and Devi, A. (2015) 'Destination Attributes and Destination Image Relationship in Volatile Tourist Destination: Role of Perceived Risk', Metamorphosis: A Journal of Management Research, 14(2), pp. 1-19. doi: $10.1177 / 0972622520150203$.

Christopher, M. and Peck, H. (2004) 'Building the Resilient Supply Chain', The International Journal of Logistics Management, pp. 1-14. doi: 10.1108/09574090410700275.

Donovan, C. (2008) 'The Australian Research Quality Framework: A Live Experiment in Capturing the Social, Economic, Environmental, and Cultural Returns of Publicly Funded Research', Reforming the evaluation of research. New Direction for Evaluation, (118), pp. 47-60. doi: 10.1002/ev.

Eden, L. and Kudrle, R. T. (2005) 'Tax havens: Renegade states in the international tax regime?', Law and Policy, 27(1), pp. 100-127. doi: 10.1111/j.14679930.2004.00193.x.
Edensor, T. (2001) 'Performing tourism, staging tourism: (Re)producing tourist space and practice', Tourist Studies, 1(1), pp. 59-81. doi: $10.1177 / 146879760100100104$.

Enright, M. J. and Newton, J. (2005) 'Determinants of tourism destination competitiveness in Asia Pacific: Comprehensiveness and universality', Journal of Travel Research, 43(4), pp. 339350. doi: 10.1177/0047287505274647.

Enteleca Research and Consultancy Ltd (2000) Tourists Attitudes Towards Regional and Local Foods, Tourists Attitudes Towards Regional and Local Foods.

Giuliani, E., Pietrobelli, C. and Rabellotti, R. (2005) 'Upgrading in global value chains: Lessons from Latin American clusters', World Development, 33(4), pp. 549-573. doi: 10.1016/j.worlddev.2005.01.002.

Goldblatt, J. (2002) Special Events: Twentyfirst century global event management, John Wiley \& Sons, Inc.

Hjalager, A. and Richards, G. (2002) 'Still undigested: research issues in tourism and gastronomy', Tourism and Gastronomy, (May), pp. 238-248. doi: 10.4324/9780203218617-20.

Humphrey, J. and Schmitz, H. (2002) 'Comment est-ce que l'insertion dans des chaînes de valeur mondiales influe sur la revalorisation des regroupements industriels?', Regional Studies, 36(9), pp. 1017-1027. doi: $10.1080 / 0034340022000022198$.

Kumar Sharma, M. and Shilpa Jain, M. (2013) 'Leadership Management: Principles, Models and Theories', Global Journal of Management and Business Studies, 3(3), pp. 2248-9878. Available at: http://www.ripublication.com/gjmbs.htm. 
McKercher, B., Okumus, F. and Okumus, B. (2008) 'Food tourism as a viable market segment: It's all how you cook the numbers!', Journal of Travel and Tourism Marketing, 25(2), pp. 137-148. doi: 10.1080/10548400802402404.

Paştiu, A. I. et al. (2015) 'Toxoplasma gondii in horse meat intended for human consumption in Romania', Veterinary Parasitology, 212(3-4), pp. 393-395. doi: 10.1016/j.vetpar.2015.07.024.

Schoen, C. (2006) 'Identifying Regional Economic Potentials', pp. 69-98.

Smith, A. (2015) 'Economic (in)security and global value chains: The dynamics of industrial and trade integration in the EuroMediterranean macro-region', Cambridge Journal of Regions, Economy and Society, 8(3), pp. 439-458. doi: 10.1093/cjres/rsv010.

Sofield, T. and Lia, S. (2011) 'Tourism governance and sustainable national development in China: A macro-level synthesis', Journal of Sustainable Tourism, 19(4-5), pp. 501-534. doi: 10.1080/09669582.2011.571693.

Sormaz, U. et al. (2016) 'Gastronomy in Tourism', Procedia Economics and Finance, 39(November 2015), pp. 725-730. doi: 10.1016/s2212-5671(16)30286-6.

Vignati, F. and Laumans, Q. (2009) 'Value chain analysis as a kick off for tourism destination development in Maputo City .', International Conference on Sustainable Tourism in Developing Countries, pp. 1-13.
Warde, A. and Martens, L. (2014) 'Eating out: Social Differentiation, Consumption and Pleasure', The Canadian Journal of Sociology, 26(3), pp. 525-527.

Wood, S. N. (2001) 'Partially specified ecological models', Ecological Monographs, 71(1), pp. 1-25. doi: 10.1890/00129615(2001)071[0001:PSEM]2.0.CO;2.

Yüksel, A. and Yüksel, F. (2001) 'The Expectancy-Disconfirmation Paradigm: A Critique', Journal of Hospitality and Tourism Research, 25(2), pp. 107-131. doi: $10.1177 / 109634800102500201$.

\section{PROFIL PENULIS}

Dr. Hary Jocom, M. Si saat ini sebagai staf pengajar dan kepala Lembaga Penelitian dan Pengabdian Masyarakat di Politeknik Bintan Cakrawala.

Prof. Daniel Daud Kameo, SE., MA., Ph. D, saat ini Guru Besar di Prodi Ilmu Ekonomi, Fakultas Ekonomika dan Bisnis, Universitas Kristen Satya Wacana.

Prof. Dr. Intiyas Utami, M.Si. Ak, CA., CMA., QIA, saat ini Guru Besar di Prodi Akuntansi, Fakultas Ekonomika dan Bisnis, Universitas Kristen Satya Wacana.

Dr (cand) Viktor Bungtilu Laiskodat, M. Si, saat ini sebagai mahasiswa program doktoral Studi Pembangunan Fakultas Interdisiplin, Universitas Kristen Satya Wacana. 